\title{
C-type natriuretic peptide levels in cor pulmonale and in congestive heart failure
}

\author{
Robert I Cargill, Craig S Barr, Wendy J Coutie, Allan D Struthers, Brian J Lipworth
}

\begin{abstract}
Background - C-type natriuretic peptide (CNP) is a recent addition to the family of natriuretic peptides which includes atrial natriuretic peptide (ANP) and brain natriuretic peptide (BNP). Whilst the levels of ANP and BNP are increased in conditions such as congestive heart failure and cor pulmonale, abnormal levels of CNP in these conditions have not been reported. Methods - Plasma levels of CNP were measured by specific radioimmunoassay in 12 young normal controls, 12 elderly normal controls, 12 patients with NYHA grade III-IV congestive heart failure, and in 16 patients with hypoxaemic cor pulmonale.

Results - Mean (SE) plasma levels of CNP were similar in young normal controls $(0.46(0.03) \mathrm{pmol} / \mathrm{l})$, elderly normal controls $(0.43(0.05) \mathrm{pmol} / \mathrm{l})$, and in patients with congestive heart failure $(0.33(0.02) \mathrm{pmol} / \mathrm{l})$. In patients with cor pulmonale, however, plasma levels of CNP were raised $(1 \cdot 39(0 \cdot 27) \mathrm{pmol} / \mathrm{l}) \quad 3 \cdot 2$-fold compared with age-matched controls.

Conclusions - In cor pulmonale the increased plasma levels of CNP were not as great as the previously observed increases in levels of ANP (5.6-fold) or BNP (18.5fold) in comparable patients. CNP may therefore be less important than ANP or BNP as a circulating counter-regulatory peptide in conditions of overactivity of the renin angiotensin system.
\end{abstract}

(Thorax 1994;49:1247-1249)

Department of Clinical

Pharmacology,

Ninewells Hospital

and Medical School,

Dundee DD1 9SY, UK

$\mathrm{R}$ I Cargill

C S Barr

W J Coutie

A D Struthers

B J Lipworth

Reprint requests to: Dr R I Cargill.

Received 16 June 1994 Returned to author 1 September 1994

Revised version received

8 September 1994

Accepted for publication

16 September 1994
C-type natriuretic peptide (CNP) has some structural similarity to atrial natriuretic peptide (ANP) and brain natriuretic peptide (BNP). ${ }^{1}$ It circulates at low concentration in normal human plasma ${ }^{2}$ but is synthesised predominantly by vascular endothelium. ${ }^{3}$ These natriuretic hormones act on guanylate-cyclase linked natriuretic peptide receptors (NPR) type $A$ or B. Whilst ANP and BNP act through NPR-A, CNP is a highly selective agonist of NPR-B which is found in vascular smooth muscle. ${ }^{4}$ In dogs the systemic actions of CNP also differ from those of ANP or BNP where CNP caused profound hypotension and re- duced cardiac output and sodium excretion. ${ }^{5}$

Serum levels of ANP and BNP are raised in states where there is circulatory pressure or volume overload with coexistent activation of the renin angiotensin system such as occurs in congestive heart failure ${ }^{6}$ and cor pulmonale. ${ }^{7}$ CNP levels, however, are not raised in congestive heart failure, ${ }^{6}$ and its role as a regulatory peptide in circulatory homeostasis remains unclear. We have therefore measured plasma levels of CNP in patients with cor pulmonale and congestive heart failure where the vascular natriuretic peptide system could potentially act as a functional antagonist of the vascular renin angiotensin system.

\section{Methods}

SUBJECTS

Normal controls

Twelve young male volunteers of mean (SE) age $25.9(1.9)$ years and 12 older volunteers (10 men) aged $68.5(1.3)$ years were studied. None were taking regular medication and all had a normal clinical history and examination, electrocardiogram, echocardiogram, and haematological and biochemical test results.

\section{Patients with congestive heart failure}

Twelve (10 men) patients aged $68 \cdot 6(2 \cdot 3)$ years with stable NYHA grade III-IV heart failure symptoms were studied. All had a left ventricular ejection fraction (LVEF) less than $40 \%$ as assessed by radionuclide ventriculography, and had been taking a constant dose of frusemide (mean dose $80 \mathrm{mg} /$ day, range $40-160 \mathrm{mg}$ ) and ACE inhibitors for at least two weeks. Patients with clinical or radiographic evidence of chronic obstructive pulmonary disease (COPD), systemic hypertension, disturbances of cardiac rhythm, or impaired renal function (serum creatinine $>170 \mathrm{mmol} / \mathrm{l}$ ) were excluded. In this group mean LVEF was $21 \cdot 6(1 \cdot 8) \%$.

\section{Patients with cor pulmonale}

Sixteen (12 men) patients aged 68.1 (1.9) years with clinically stable cor pulmonale secondary to COPD were studied. All had spirometric results reflecting COPD $\left(\mathrm{FEV}_{1} / \mathrm{FVC}<70 \%\right)$, arterial hypoxaemia while breathing air $\left(\mathrm{PaO}_{2}\right.$ 
$<8.0 \mathrm{kPa}$ ), had been taking a constant dose of frusemide (mean dose $71 \mathrm{mg}$ /day, range 40-160 mg) but not ACE inhibitors, and had or gave a history of having peripheral oedema despite normal left ventricular function (on echocardiogram or radionuclide ventriculography), normal renal function (serum creatinine $<170 \mathrm{mmol} / \mathrm{l}$ ), and normal serum levels of albumin (>35 g/l). Patients with systemic hypertension or atrial fibrillation were excluded. In this group $\mathrm{FEV}_{1}$ was $0 \cdot 78(0 \cdot 12) 1$ (range $0.30-1.49 \mathrm{l}$ ), $\mathrm{FEV}_{1}$ as \% of predicted $30 \cdot 2(2 \cdot 6) \%$ (range 15-42\%), $\mathrm{PaO}_{2}$ on air $6.09(0.29) \mathrm{kPa}$ (range $3.95-7.49 \mathrm{kPa}$ ), and $\mathrm{PaCO}_{2}$ on air $6 \cdot 48(0 \cdot 32) \mathrm{kPa}$ (range $3 \cdot 40-8 \cdot 44 \mathrm{kPa})$.

\section{ASSAY PROCEDURE}

Approval was obtained from the Tayside committee for medical ethics. After giving informed consent subjects rested supine for 30 minutes while breathing room air. Venous blood was collected into EDTA tubes with aprotinin (Trasylol; Bayer UK Ltd, Newbury, Berkshire, UK) before centrifugation and plasma was stored at $-70^{\circ} \mathrm{C}$.

Plasma levels of CNP were measured using a commercially available radioimmunoassay kit (Peninsula Laboratories Inc, Belmont, California, USA) after solid phase extraction from plasma proteins. Mean CNP recovery was $54.7 \%$ and the intra-assay coefficient of variation was $11 \cdot 4 \%$. The anti-CNP antibody used had no cross-reactivity with either ANP or BNP.

\section{DATA ANALYSIS}

Comparisons were made by analysis of variance and Duncan's multiple range testing using a Statgraphics (STSC Software, Maryland, USA) package. Results are expressed as mean(SE).

\section{Results}

The plasma CNP concentration was similar in both young $(0.46(0.03) \mathrm{pmol} / \mathrm{l})$ and elderly $(0.43(0.05) \mathrm{pmol} / \mathrm{l})$ normal subjects. In patients with congestive heart failure the plasma CNP concentration was not significantly different from young or elderly controls at $0.33(0.02) \mathrm{pmol} / 1$. In patients with cor pulmonale, however, the plasma CNP concentration was significantly $(p<0.05)$ increased

\footnotetext{
Plasma levels of $C$-type natriuretic peptide (CNP) in 12 young normal controls (YN), 12 elderly normal controls (EN), 12 patients with congestive heart failure (CHF), and 16 patients with cor pulmonale (CP). Bars indicate mean values and indicate mean values and significant $(p<0.05)$ difference from $Y N, E N$, and from congestive heart failure.
}

at $1 \cdot 39(0 \cdot 27) \mathrm{pmol} / \mathrm{l}$ compared with young or elderly controls and with congestive heart failure patients. To accommodate the one outlying data point in the cor pulmonale group, the trimmed mean of the other 15 values was calculated to be $1 \cdot 18(0 \cdot 19) \mathrm{pmol} / 1$, significantly $(p<0.05)$ higher than the other three subject groups. In patients with cor pulmonale plasma levels of CNP did not correlate with $\mathrm{PaO}_{2}$, $\mathrm{PaCO}_{2}$, or $\mathrm{FEV}_{1}$.

The plasma CNP concentration was therefore raised $3 \cdot 0$-fold in patients with cor pulmonale compared with young normal controls and 3.2-fold compared with age and sex matched elderly normal controls. Individual values with sample means are depicted in the figure.

\section{Discussion}

These findings indicate that, despite similar activation of the renin angiotensin system in patients with cor pulmonale and congestive heart failure ${ }^{78}$ circulating CNP levels are raised in cor pulmonale but not in congestive heart failure. We should therefore briefly consider possible explanations for this observation.

Little is known regarding the stimuli for CNP synthesis and release, although plasma levels of CNP are unaffected by the acute pressor effects of angiotensin II in normal subjects. ${ }^{9}$ Differences in vasodilator therapy between these groups - that is, ACE inhibition in the congestive heart failure group causing a reduction in vascular stretch - are therefore less likely to be a valid explanation. Reduced clearance of CNP is also unlikely to explain these differences, given that renal function was similar in patients with cor pulmonale and congestive heart failure, although how this is affected by hypoxaemia is unknown.

The other obvious difference between the two patient groups is the presence of arterial hypoxaemia. Whether hypoxaemia stimulates CNP release, as is the case with $A N P,{ }^{10}$ is unknown. Alternatively, chronic arterial hypoxaemia may cause sufficient endothelial damage to allow CNP to leak out into plasma in greater quantity.

Plasma levels of CNP in normal subjects in other studies have been somewhat higher than our own ${ }^{6}$ even after conversion into the same SI units. The differences may be partially explained by the use of differing assay methodology. Our method gave $54.7 \%$ CNP extraction whereas other methods appear to have higher CNP extraction efficiency. The observed pattern of raised CNP levels in patients with cor pulmonale is, however, still valid in comparison with controls and congestive heart failure patients where the assay methodology was identical.

Despite the present finding that plasma levels of CNP are significantly raised in patients with cor pulmonale, it would appear that ANP and BNP are the predominant circulating natriuretic peptides since ANP is increased 5.6fold and BNP 18.5-fold in comparable patients. ${ }^{7}$ CNP may therefore act mainly as a paracrine agent within vascular tissue rather 
than as a circulating hormone involved in cardiovascular homeostasis. Thus, measurement of plasma CNP levels and studies involving systemic infusions of CNP may have only a limited role in clarifying its physiological significance.

This research programme was supported by the Scottish Hospital Endowments Research Trust.

1 Komatsu Y, Nakao K, Suga S, Ogawa Y, Mukoyama M, Arai $\mathrm{H}$, et al. C-type natriuretic peptide in rats and humans. Endocrinology 1991;129:1104-6.

2 Stingo AJ, Clavell AL, Heublein DM, Wei C, Pittelkow MR, Burnett JC. Presence of C-type natriuretic peptide in cultured human endothelial cells and plasma. $A m \mathcal{F}$ in cultured human endothe

3 Suga S, Nakao K, Itoh H, Komatsu Y, Hama N, Imura H Endothelial production of C-type natriuretic peptide and its marked augmentation by transforming growth facto B. $\mathcal{F}$ Clin Invest 1993;90:1145-9.
4 Koller KJ, Lowe DG, Bennett GL, Minamino N, Kangawa $\mathrm{K}$, Matsuo $\mathrm{H}$, et al. Selective activation of the B-natriuretic peptide receptor by C-type natriuretic peptide (CNP) Science 1991;252:120-3.

5 Stingo AJ, Clavell AL, Aarhus LL, Burnett JC. Cardiovascular and renal actions of $\mathrm{C}$-type natriuretic peptide. Am $\mathcal{}$ Physiol 1992;262:H308-12.

6 Wei CM, Heublein DM, Perrella MA, Lerman A, Rodeheffer RJ, McGregor CGA, et al. Natriuretic peptide ystem in human heart failure. Circulation 1993;88:1004-9.

7 Lang CC, Coutie WS, Struthers AD, Dhillon DP, Winter JH Lipworth BJ. Elevated levels of brain natriuretic peptide in acute hypoxaemic chronic obstructive pulmonary disease. Clin Sci 1992;83:529-33.

8 Burnett JC, Kao PC, Hu DC, Heger D, Heublein D, Granger J, et al. Atrial natriuretic peptide elevation in congestive heart failure in the human. Science $1986 ; 231$ : 1145-7.

9 Cargill RI, Coutie WJ, Lipworth BJ. The effects of angiotensin II on circulating levels of natriuretic peptides. Br f Clin Pharmacol 1994;38:139-42.

10 Baertschi A, Adams JM, Sullivan MP. Acute hypoxaemia stimulates atrial natriuretic factor secretion in vivo. $\mathrm{Am} \mathcal{F}$ Physiol 1988;255:H295-300.

\title{
Effect of exercise on the nasal transmucosal potential difference in patients with cystic fibrosis and normal subjects
}

\author{
S Alsuwaidan, A Li Wan Po, G Morrison, A Redmond, J A Dodge, J McElnay, \\ E Stewart, C F Stanford
}

\section{School of Pharmacy, The Queen's University of Belfast \\ $S$ Alsuwaidan \\ A Li Wan Po \\ J McElnay}

Royal Belfast Hospital for Sick Children

G Morrison

A Redmond

J A Dodge

Royal Victoria

Hospital

E Stewart

C F Stanford

Belfast, UK

Reprint requests to: Dr C F Stanford,

Department of Medicine,

King Khalid National Guard

Hospital,

Jeddah 21423, PO Box

516

Saudi Arabia.

Received 22 January 1992

Returned to authors

10 April 1992

Revised version received

7 June 1994

Accepted for publication

9 September 1994

Mean (SE) effects of exercise on the nasal transmucosal potential difference in patients with cystic fibrosis and controls

\begin{tabular}{lllll}
\hline & $\begin{array}{l}\text { Before } \\
\text { exercise }\end{array}$ & $\begin{array}{l}\text { After } \\
\text { exercise }\end{array}$ & $\begin{array}{l}\text { Greatest change } \\
\text { after exercise }\end{array}$ & Recovery \\
\hline Cystic fibrosis $(\mathrm{n}=7)$ & $-27 \cdot 6_{*}^{(5 \cdot 8)}$ & $-17 \cdot 7(5 \cdot 2) \dagger$ & $-16 \cdot 6(5 \cdot 5) \dagger$ & $-32 \cdot 6(5 \cdot 9)$ \\
Controls $(\mathrm{n}=7)$ & $-12 \cdot 0^{*}(2 \cdot 1)$ & $-19 \cdot 8(2 \cdot 4) \dagger$ & $-22 \cdot 1(3 \cdot 2) \dagger$ & $-17 \cdot 2(2 \cdot 8)$ \\
\hline
\end{tabular}

* Differences within columns $(p<0.05)$

$\dagger$ Differences between resting and subsequent values within rows $(p<0.05)$. the results for the patients with cystic fibrosis had returned to their resting values. Conclusions - Exercise reduces the abnormally high resting values for nasal TPD in patients with cystic fibrosis. Elucidation of the mechanism for this change may help to produce functional improvement for patients with this disease.

(Thorax 1994;49:1249-1250)

Cystic fibrosis is characterised by an increase in thick mucous secretions. A defective transmembrane regulator for chloride transport in epithelial cells, unable to open under the influence of cyclic AMP, has been described. ${ }^{1}$ Respiratory epithelial cells from patients with cystic fibrosis also have a high sodium absorption from the mucosal surface which causes a more negative transmucosal potential difference (TPD) than in controls. ${ }^{2}$

Exercise causes an increase in nasal secretion in normal subjects. ${ }^{3}$ TPD also increases in normal subjects during exercise, a change probably related to the increase in secretion. ${ }^{4}$ The current study was performed to see if the nasal TPD behaved in the same way during exercise in patients with cystic fibrosis and healthy subjects.

\section{Methods}

Seven patients with cystic fibrosis (four men) aged 9-24 years and seven age and gender matched healthy controls volunteered for the 